Editorial

\title{
“NOTHING HUMAN IS ALIEN TO ME": RETHINKING HISTORICAL MATERIALISM AND SOCIALISM
}

\author{
ELAINE COBURN \\ Centre d'analyse and d'intervention sociologiques (CADIS)-Ecole des Hautes Etudes en \\ Sciences Sociales and American University of Paris. Paris, France. ${ }^{1}$
}

\begin{abstract}
Biographical Note
Elaine Coburn has been the Co-Editor and Editor of Socialist Studies from August 2009 to July 2014. She is assistant professor at the American University of Paris and researcher at the CADIS, Ecole des Hautes Etudes en Sciences Sociales. Her recent work is collaborative research around discourses of the International Monetary Fund and World Bank over the last forty years and Indigenous resistance and resurgence. She may be reached at coburn.elaine@gmail.com.
\end{abstract}

\begin{abstract}
Historical materialism emphasizes antagonistic class relationships as the main characteristic of the social, hence historically contingent, capitalist mode of production. Socialism is a normative vision of a just society rooted in meeting needs and enabling unalienated human expression, within the ecological limits of the natural world. Both are useful, even critical ways of understanding the world and seeking to bring about a better one. However, both are radically inadequate. Indeed, some scholars charge that both are worse than useless. The most serious critique is that historical materialism and socialism collaborate in silencing other anti-oppressive theories and struggles, by insisting on exclusive "class-only" approaches. After describing three characteristic ways that many historical materialists do, in fact, collaborate to exclude many important anti-oppressive theories and struggles, I argue - following many others - that such exclusions are not tenable on analytical, empirical, moral and practical grounds. In fact, historical materialism and socialism have much to gain with a more inclusive approach, although that inclusiveness might take different forms. For instance, Indigenous, Black power and gay and lesbian movements are instances of anti-oppressive theories and struggles that offer critical insights into actually-existing capitalism; and the potential for transformative change within and even beyond capitalism. Class inequalities are inextricably bound up with other sources of oppression, rooted in race, gender, disability, sexuality and ongoing colonialism - which are not 'essential' inequalities but
\end{abstract}

\footnotetext{
1 Thank-you to all for my last five years as editor of Socialist Studies, including two as co-editor with Chad Thompson. I've enjoyed my exchanges with the Society of Socialist Studies executive and others members, guest editors, contributing authors, peer reviewers, book editors Murray Cooke and Adrian Smith, layout editor Sean Cain, and my time co-editing with Chad. And I have learned a great deal. The next editor, Sandra Rein, brings new perspectives and energies to Socialist Studies, which is fortunate to have her.
} 
social, historically emerging and hence contingent oppressions. Put another way, understanding capitalism includes theorizing the ways that capitalist social relations create ecological 'niches', as lan Hacking might say, for a range of interrelated unjust inequalities. Further, all oppressions must be fought in themselves, as part of socialist commitments, because they inhibit the free unalienated expression of each and all. The revised historical materialism and socialism that result from this are more modest because they do not aspire to attribute all "major" capitalist dynamics exclusively to class. But they are also more ambitious, because they are in a necessary, constant dialogue with other anti-oppressive theories and struggles.

\section{Keywords}

anti-racism, ecological niche, gender inequality, intersectionalism, historical materialism, oppression, socialism

Historical materialism is a particular, useful - but also radically inadequate - way of analysing the contemporary capitalist world. Likewise, socialism, as a vision of a plausible just society emerging out of contemporary prefigurative struggles for social justice, is often inadequate. Indeed, below, I will consider the hypothesis that historical materialism and socialism are not just inadequate but worse than useless. This echoes arguments by other historical materialists, for instance, anthropologist Eleanor Leacock who argued that "oppression and exploitation by sex, race and class are fundamental in the contemporary world" and "theories which ignore this reality are meaningless, if not downright destructive" (quoted in McCoid 2008, p.25). With Leacock and others, I go on to argue that historical materialist and socialist legacies are worth defending but only if they are reconsidered in important ways. The future of historical materialist and socialist theory lies in transformed visions and practices, so that both become simultaneously more modest and more ambitious. More modest, because they must be in a constant dialogue with other anti-oppressive theories and struggles around race, gender, sexuality, disability, colonialism, as well as ecological movements. Such dialogue will not leave historical materialism and socialism unchanged. This means a renewed historical materialism and socialism will also be more ambitious, precisely because it must take into account these other theories and movements. ${ }^{2}$

There are analytical reasons for taking many unjust equalities seriously when developing richer historical materialist theories of actually-existing capitalisms and of historical transformations within world capitalism. Below, for instance, I describe a recent attempt by

\footnotetext{
2 As stated, this call for a simultaneously more ambitious and more modest historical materialism and socialism suggests somewhat distinct and apparently contradictory visions. One calls for historical materialism and socialism to be in dialogue with other theories and struggles against unjust social inequalities. The other approach suggests a reformed historical materialism and socialism that take complex struggles against unjust social inequalities seriously as integral parts of historical materialist theorizing and in everyday socialist struggles. Arguably, these are differences in emphasis, complementary rather than contradictory, since both take seriously unjust inequalities around historically contingent constructions of difference. In practice, seeing both would be useful; the problem is a dominant status quo that too often does neither.
} 
Mbembe (2013), in a genealogical rather than historical materialist vein, that illuminates centuries of human history through the principle of the 'nègre'. The 'negre' appears both as a complex and contradictory symbol and as a material reality embodying relations of extreme violence, in which racialized human beings are no longer ends in themselves but merely means. Among other contributions, Mbembe's analysis sheds critical light on the workings of capitalism and the ways that a shape-shifting racism fits into the capitalist tendencies to commodification, not least of racialized human life, over centuries, from slavery to the present. Hence, there are good analytical reasons for historical materialists and socialists to be alert to such scholarship, simply from the point of view of seeking to understand central capitalist dynamics.

However, the underpinnings of my argument here for taking many unjust inequalities seriously, are not only analytical but also empirical. World capitalism is not only about class, as if class existed in some pure form outside of race, gender, sexuality, disability and colonialism. Capitalism and class have always been thoroughly mixed up with these other unjust inequalities, as Himani Bannerji (2005, p.144) might put it. That these are social, hence contingent and changing over decades and centuries of the world capitalist mode of production does not make these inequalities any less real in their social consequences. For that matter, unequal capitalist class relationships are equally contingent but nonetheless shape social life in profound ways. Less contingent, but increasingly obviously as a critical concern for the ongoing viability of human and other life, historical materialist theory and socialist practices must take into account the fact that the ultimate context for all life is the natural world upon which we and other living things depend. Political economy is not the final context, rather the natural world poses limits that must be respected to sustain human and other life.

Finally, the argument for a revised historical materialism and socialism is ultimately rooted in moral grounds, as well as analytical and empirical ones. It takes seriously the maxim that Marx took as his own: "Nothing human is alien to me"3 (Marx 1865). Put starkly, human suffering within capitalism is not only about class; human liberation is not reducible to class revolution. Moreover, human and other forms of life are not possible without a sustainable ecological context. This doesn't mean historical materialism and socialism are dead - only that they must go on living in new/old ways to struggle for liberation for human beings as they are and not as reductionist theories imagine them to be. This is not a new argument (see, for example, Belkhir 1994, Gimenez 2001 as just two instances of some earlier debates) but they do bear repeating. Pragmatically, socialism will only be relevant again when socialists learn to hear

\footnotetext{
3 This saying is originally from the ancient Roman playwright Terence. Of course, you could argue that one aim of socialism is to create a more just social world in which the injustices of contemporary world capitalism will appear alien, in the same way that historical social relations and very different cultures than our own often feel alien to us. Here, I take this saying to mean that we should be interested in human life in all its variety, not as imagined in crude versions of Marxist class theory. In other words, in citing this favourite quotation of Marx, I am not taking a stand against pluralism or the persistence of - or invention of - alternative ('alien') worldviews and social relations; on the contrary, it seems to me that free human expression will mean a more plurality with respect to ontologies, epistemologies and so on.
} 
and support the voices and struggles of working and dominated peoples in all the complexity of their lived experiences within capitalism.

\section{Flogging a Dead Horse?}

Some will argue that I am flogging a dead horse. Here, I use arguments put forth in 2001 by Gimenez as way to briefly address that argument. Over a decade ago, Gimenez (2001) wrote somewhat wearily that "in early feminist literature", "Marx and Marxists were criticized for not developing an in-depth analysis of the oppression of women, their 'economism', 'class reductionism', and 'sex-blind' categories of analysis. Soon after it became common place to assert that Marxism was also at fault for neglecting race, demography, ethnicity, the environment and practically everything that mattered to the 'new social movements' in the West" (p.24). Gimenez argues, if it is not already evident, that this criticism was misplaced, since she "suspect(s)" that most Marxists teaching social stratification were already adept practitioners" (p.25) around questions of race, gender and class. This is rooted, she argues, in Marx's own historical materialist appreciation of the fact that "we are, in Marx's terms, "an ensemble of social relations"” (Gimenez, p.25, italics in original). Hence, Marxists have always grappled with these issues, but they have done so in ways that are more theoretically informed than in intersectionality paradigms pioneered by feminist women of colour based in the United States. According to Gimenez, "intersectionality" advocates merely document the empirical existence of the ways that lives are gendered and racialized, usually be appealing to "experience", which supposedly transparently reflects social location within unequal relations (p.30). But those advocating intersectionality do not theorize unequal relations nor do they recognize that experience is often problematic, mystified by dominate ideologies. Moreover, "class" concerns are stripped of their antagonistic relational characteristics within the capitalist context and class becomes simply a matter of identity that is, in any event, the least important in the "trilogy". This relative neglect is explicable on historical materialist grounds: class is the least relevant among race, gender and class, at least in the American context, because of the legacies of McCarthyism, a relatively weak working class and the associated rise of new social movements of the 1960s that ideologically limited "class" within broader public but also academic political debates (p.28).

Does my argument here fall into this intersectionalist attack on historical materialism and socialism? With Gimenez (2001), I do think it's problematic to evoke "race, gender and class" without considering how these are articulated within world capitalism, across five centuries of empire and today in different national polities. Indeed, many apparently banal human differences only become socially relevant at specific moments. Hacking (1998, pp.55-56) might argue that when and how this occurs depends upon the emergence of an "ecological niche" enabling the emergence of a particular inequality as a social fact. World colonial-capitalism, not least class struggles and other movements, are part of what constitutes the ecological niches that enable - or work against - the emergence and persistence of various 
unjust social relations around human differences. The tendency to treat some human being as "things", as means rather than ends, for instance, is surely at least partly the product of ecological "niches" created within a world capitalist systems that tends to reduce humans to labour power, hence a simple variable contributing to profit-making for capital. However, world-colonial capitalism is not the whole context, which might include related dynamics, not least ongoing colonialisms, racisms, patriarchal relations and so on. Moreover, against Gimenez, I am sceptical of the argument that historical materialists and socialists have consistently considered class in relation to other unjust, historically contingent inequalities and I offer some suggestive empirical evidence for this claim, below.

In addition, with theorists like Patricia Hill Collins (2009), I am less dismissive of "experience" than Gimenez. I would argue that experience is an important way of knowing, not least against expert formal theorizing, including knowing what it means to be working class. This is true even if that experience is not unmediated, not least by a privately owned media that contributes to a popular culture that fragments, distorts and suppresses many class realities and ongoing class and subaltern struggles. Indeed, I might even go further and suggest that theory and experience are not binary opposites, so that experience can become an important source of theoretical insight and development. Smith (2004, pp.47-49), for instance, explains how she began to develop what has become a distinctive institutional ethnographic feminism 'from Marx', in part because, as originally formulated, the Marxist political economic theories she learned at graduate school had literally nothing to say about her everyday experiences as a single mother. Finally, I believe that Gimenez - as an example of a certain kind of historical materialist attack on intersectionalist theory - does an unfortunately typical disservice to historical materialism and socialism in her concluding arguments. Specifically, she writes that "From the standpoint of Marxist theory, however, class is qualitatively different from gender and race and cannot be considered just another system of oppression" (Gimenez p.30). The "just another" unhelpfully suggests that such other oppressions don't really matter. An implication appears to be that racialized working class and subjugated people, for instance, are simply misdirecting their energies by expressing concerns about the fundamental ways race shapes their lives in everything from education to housing to employment to risks of violence and imprisonment, not least in the contemporary North American and European context. This trivializes such inequalities; indeed, it is arguably meant to trivialize them against the central, apparently uniquely critical dynamic of unequal and exploitative class relations.

Gimenez justifies her observation by suggesting, after Terry Eagleton, that class is not "unremittingly bad" unlike racism and sexism, which are purely negative; hence class is analytically and strategically different in struggles to transform and go beyond capitalism. But this claim depends upon a false parallel between class and racism and sexism - it should be class and race and gender, where all of these are socially contingent relations of inequality that take particular forms in different moments across world capitalism. Moreover, in making such a claim, Gimenez must overlook the ways that working class struggles never appear in "pure" 
forms as sites for solidarity and liberatory social change. Thus, for instance, the slave revolts that resulted in Haitian independence in 1804 can only be understood as the resistance of an oppressed racialized class of unfree labour. To assume that racial solidarity played no part in that revolt is an absurd abstraction from the actually-lived history of slavery. Nor can such movements of freedom be considered incidental; through liberation, they certainly radically changed the immediate material conditions of many former slaves, even if too many workers continue to labour in slave-like conditions and even if many racialized workers are still engaged worldwide in unfree labour. The symbolic charge of slave liberation likewise matters against the supposed natural fatality of slavery and against racist assumptions that some human beings are less-than-human "nègres". Likewise, it is simply untrue to suggest that women's movements, including early movements for women's suffrage for instance, have been "just another" struggle against oppression, one that has not meaningfully changed capitalism nor working women's lives. It does matter, for instance, that women have prospects that are larger than domesticity; better, if not yet equal pay for women does make a real difference in working class women's lives. It is not incidental that adult women are now legally considered autonomous humans and not simply wards of fathers and spouses - if not in all, in many contemporary contexts. Unfortunately, far from flogging a dead horse, these are still critical debates and conversations that need to happen about historical materialism, socialism and how they relate to fighting injustice in all its forms within world capitalism. This paper seeks to contribute to these debates.

\section{Historical Materialism and Socialism's Distinctive But Inadequate Contributions}

Briefly, I would say that historical materialism emphasizes the historically changing and contingent nature of human life, which is always social life. We are born into relations that we did not choose; but these are not the eternal products of a fixed human nature but the contingent outcome of collective human struggles. ${ }^{4}$ Specifically, historical materialism maintains that understanding contemporary social life means recognizing the world political economic context of capitalism. According to historical materialist theories, the contemporary world capitalist mode of production, which has undergone important transformations over the last five centuries and which exists in somewhat different national forms, is characterized - some would argue first and foremost - by antagonistic class relationships. How people get together to make what is needed to live, the mode of production, is fundamentally about this exploitative class

\footnotetext{
${ }^{4}$ This does not mean that there is no such thing as human nature, only that social structures do not spring forth directly from human nature in a pure, unadulterated and hence unchanging form. In fact, human nature may often be thwarted by unequal social relations that weigh like a nightmare over human inclinations, for instance, as when the desire to develop and express diverse talents is made impossible by the demand for a repetitive, limited labour repetoire, because the latter is more efficient hence more profitable for capitalist owners. Since historical materialism is attuned to the historically changing nature of social life, it is alert to the wide range of what comes to seem natural, across different historical periods but also in different cultural contexts - as anyone who has travelled outside their home culture has experienced, when they discover their reflexes are not universal.
} 
relationship. Specifically, there is a transnational capitalist class and there are dominated classes, including the working class that sells their labour to make a living but also the "army of the unemployed" and underemployed, subsistence farmers faced with the threat and reality of dispossession, the masses of incarcerated and many other subaltern classes. These class relationships are marked by extreme inequalities. There are small numbers of global billionaires, increasingly living off inherited wealth rather than income (see Piketty 2013, for a non-socialist recent empirical account) - seeking to fulfill increasingly esoteric desires. Many others live short and stunted lives subject to persistent threats of violence, hunger and the outfall of human-made ecological disasters. This is a zero-sum relationship; the world's billionaires are actively dispossessing and exploiting the majority of humanity. So-called 'primitive accumulation', including the dispossession of Indigenous peoples, peasants and others is often ruthlessly pursued by multinational resource extraction corporations, including with the cooperation of (sometimes still-colonial) states. However, historical materialism reminds us that such unjust relationships need not be so, since human relations are products of human struggle, hence contingent. The injustices that are so ordinary within capitalism may be challenged and overthrown. This may not be a probable outcome, but it is a possible one; in such struggles, both progressive reform and revolution matter - indeed any steps that improve the immediate situation of dominated classes and groups are important, including for the strategic reason that they are concrete reminders that change is possible.

In this way, historical materialism is obviously related to, if distinct from, the project of socialism. Historical materialism offers analyses of actually-existing capitalism. It does so as a spur to fundamental social transformation, as Marx reminds us in his famous phrase "The philosophers have only interpreted the world, in various ways; the point, however, is to change it" (Marx 1888). As expressing a commitment to action, socialism may be characterized as a normative but plausible project for a just world that could come into being. Although there are many definitions of socialism, here, I suggest that they are animated by two major principles, to which a third is increasingly (rightly) added. The principles underlying socialist justice are first, "to each according to need", and second, the rather less austere commitment to the unalienated human expression of each and all. ${ }^{5}$ A third element, borrowed from the ecological movement but congruent with many of Marx's own observations (Foster 2000), is respect for all living things and the natural world as the bases for sustaining all of life, including human life. Although socialists sometimes undertake an abstract, normative theorizing - of the kind typified by GA Cohen through the last decades of his life (see Cohen 2009) - arguably the most useful socialism is praxis, that is, on the ground struggles. "Be the change you want to see", from

\footnotetext{
5 This is admittedly a somewhat idiosyncratic interpretation of "from each according to ability," stressing the possibility of expressing abilities and talents rather than the social obligation of each to participate according to ability. Arguably, such an interpretation avoids hard questions about what people owe to others, instead emphasizing the importance of not being alienated from talents.

${ }^{6}$ This is not to suggest that abstract normative theorizing around socialism does not matter, not least because such approaches challenge the monopoly of liberal theories within political and moral philosophy, reintroducing critical
} 
Gandhi, is the slogan that best captures the idea of socialism as prefigurative practice. Or, somewhat differently and recognizing the difficulties of creating new worlds out of the ashes of the old, "how we will come out of the revolution will depend very much on how we will go into it" (Stoetzler quoted in Holloway 2012, p.335) Put another way, socialism is made plausible as more than an ideal through struggles and actions that live out commitments to meeting needs, freeing human individuals to express their varied talents and respecting the natural world.

What, then, is the problem with historical materialism, as a theory offering insights into actually existing capitalism, and with socialism, as a normative vision of a just world rooted in contemporary struggles, first, to meet needs within life-sustaining ecological limits and second, to enable unalienated human expression? The first major problem for historical materialism is that it does not live up to its own historical materialist premises. By this, I mean that too many historical materialist analyses ignore fundamental realities of human lives, of human suffering and of human solidarity within capitalism, on the grounds that inequalities around race, gender, sexuality, colonialism and disability are not "essential" aspects of the world capitalist political economy. They maintain this even in the face of overwhelming evidence that such unjust inequalities shape everyday life for the vast majority of humanity within actually-existing capitalism. I have tried to emphasize that unjust inequalities are neither natural nor ahistorical. Rather, they are social, hence contingent and historically changing; they must be theorized and their emergence and transformations cannot be deduced but must be empirically investigated. But they cannot be ignored on the grounds that they are "just another" form of oppression, hence unworthy of investigation. In addition, in historical materialist theory too many write as if the ultimate context for social life were the world capitalist political economy and not the natural world that sustains us. This is sometimes stated explicitly, sometimes implicitly, as I explore below, and these omissions are often institutionally organized - which should come as no surprise to materialist theorists.

Second, on both empirical and moral grounds, it is not simply a matter of "live and let live" in a world in which historical materialists and socialists focus on class revolution while other anti-oppressive moments occupy themselves with other unjust inequalities in a clean division of labour. There could be differences of emphases, with some approaches primarily emphasizing gender, for instance, and others stressing class. But a 'clean' division of analytical and empirical labour is impossible, insofar as these other inequalities are thoroughly mixed up with class and with each other. As already observed, following Bannerji (2005), we do not experience race, gender, class - and disability, sexuality etc. - separately and sequentially but all together and all at once ${ }^{7}$. At the same time, how these are experienced and how they are

concepts, like equality and community back into debates about justice. Academia is one arena of struggle, if not the only one nor the most important one.

7 Of course, the tendency to pretend that these experiences are separate and sequential takes historically sedimented institutional forms. The book title, All the Women are White, All the Blacks are Men, But Some of Us are Brave: Black Women's Studies (Hull, Bell-Scott and Smith 1982) succinctly captures how this plays out in academia, with white gender studies and masculinized Black studies- and this paper follows these authors in calling for brave challenges to 
articulated with broader capitalist relations are not fixed but change over time and across different national contexts.

On moral grounds, insofar as socialist struggles “overlook" inequalities -for instance, around race, gender, disability, sexuality, ongoing colonization, and so on, they reproduce such injustices. In the familiar rhetoric of social movements, if historical materialism and socialism are not part of the solution with respect to these other unjust inequalities, they are part of the problem. Third, historical materialism and socialist struggles have been marginalized for decades for multiple reasons, not least the relative increasing strength of the world capitalist class and hence the relative decline of the dominated classes. During the same time period, however, elements of the working and dominated classes have made critical gains in anti-racist struggles, including the successful struggle against legal apartheid in South Africa, improvements to women's equality if certainly not an end to male domination, and so on. Both historical materialism and socialism are doomed to continued irrelevancy if they dismiss major, everyday sources of suffering and also solidarities on the grounds that these are illusory because they are not "primarily" concerned with class. In other words, although they do have vital insights, historical materialisms and socialisms are inadequate on quadruple analytical, empirical, moral and pragmatic grounds insofar as they marginalize questions around race, gender, sexuality, colonialism, disability and the natural world. They may even be harmful insofar as they perpetuate non-class based injustices. Since injustices may arise and take new forms, while others disappear, historical materialists must be alert to how both new and old unjust relations of inequality are articulated within world capitalism at any time.

Fortunately, not all historical materialists and socialists may be characterized this way. There have been and are struggles for black socialisms, feminist socialisms, lesbian, gay, bisexual, transexual and transgender socialisms, disability advocacy socialisms, anti-colonial socialisms and ecological socialisms - and no doubt more, including some that we cannot anticipate that will arise in the future. Throughout this paper, I draw on some of these underrated contributions. Indeed, as historical materialist and socialist scholars, one task ahead is to bring these scholars and activists back "from margin to centre" as bell hooks (2000) puts it. So doing will create a more accurate but also more useful memory of actually-existing historical materialist analysis and socialist activism. But this is an essential effort on its own terms, because bringing race, gender, sexuality, Indigenous struggles, and disability advocacy "back in" is about analysing and struggling from human life as it actually is - in the past and right now - and not as it is imagined in some analytically pure class theory. If we take seriously Marx's maxim that "Nothing human is alien to me", then it means taking into account the complex ways that suffering and solidarity is manifest within world capitalism. Socialist struggles can only pretend to liberation for each and all when they account for the actually-lived experiences of the dominated classes in all of their humanity. That is a big task and it is practical one, at least as much as it is a theoretical and empirical challenge. Below, I sketch out what historical materialist

such institutionalized boundaries. 
theories and socialist practices would look like if they were to (begin to) do this, building on at least a century of past efforts that also tend in this direction. But before that, I examine some serious charges against historical materialism and socialism, including the argument that they are not merely inadequate but actually damaging, worse than useless.

\section{Are Historical Materialism and Socialism Worse Than Useless?}

I have said that historical materialism and socialism are inadequate. But some might argue that the situation is much more serious than that: historical materialism and socialism are not inadequate. They are not even useless. Rather they are worse than useless. One ground for making this argument is the horrors of the ostensibly Communist regimes of Eastern Europe, China and so on. As my colleague Augustin ('Catalin') Stoica used to tell me when we were graduate students, having survived life and struggles against Ceausescu's regime in Romania: "I've lived your utopia!". To me, the obvious answer is that these regimes were not Communist in any meaningful sense of the world. Certainly, they were not "socialist" if socialism is about meeting needs and the unalienated expression of each human being. The draconian limits on human freedoms so characteristic of these regimes, not least the drastic limits to the free expression of ideas, are not compatible with socialism thus imagined. Neither, it should go without saying, is mass murder and starvation, mass incarceration and torture. The explicit, formal censorship of these regimes and the horrendous persecution of dissidents and ordinary prisoners has nothing to do with what GA Cohen might have called a socialist "ethos" (2009, e.g., pp. 344-56) of community and solidarity. If Romania were socialist, then socialism would rightly be struggled against as a horrifying prospect -- but I don't think that the case can even remotely be made that such regimes' fulfill socialist criteria of meeting needs and unalienated self-expression. They were also, typically, ecological disasters.

Observing this does not exonerate the countries of the West. North American and Western European states are guilty of anti-Communist witchhunts and de facto limits on free expression given a privately-owned so-called "free" press. There are, moreover, the realities of mass incarceration, not least in the United States but also in Canada. These injustice systems "capture", as Sakej Youngblood Henderson (forthcoming) vividly describes it, subaltern masses, particular poor Black, Indigenous and other racialized minorities. There are the seemingly never-ending entanglements in imperial wars, which are typically deadly to those being "rescued" by a Western military itself made up of racialized and working class men and some women. There are the facts of contemporary slavery, a brisk world-wide trafficking of organs and human beings, including in the sex trade, with the world's working and underclasses literally supplying bodies and body parts to the wealthy and infirm in the West (see, for instance, Scheper-Hughes 2001). But Communist nations are not exemplars of socialism, any more than contemporary Western nations live up to democratic liberal ideals of freedom and equality.

Some might argue that this is an intellectual pirouette to save socialism and that 
"actually-existing" socialisms must be analysed just as actually-existing capitalisms are. But that a murderous dictator calls his regime socialist does not make it so. Indeed, to admit Ceaucescu's claim is to disfigure socialist contributions from Marx to Rosa Luxemburg to GA Cohen and Himani Bannerji to those of many more anonymous and admirable people who have fought nationally and internationally for socialism. They have done so partly in the name of self-expression and freedoms, because these will be rooted within shared material well-being that makes the genuine exercise of those freedoms possible. In fact, far from being present in the self-declared Communist regimes, if there have been embryonic expressions of socialism, these are not embodied by any national state. Instead, they are found in the interstices of the world political economy, in cooperatives, in persistent patterns of informal sharing, and in examples of joyous solidarity combined with individual fulfillment, like playing in a jazz band (Vrousalis 2012).

An equally serious but to me more credible charge against historical materialism and socialism is that they have often collaborated with racism, sexism, homophobia, disabling social relations and structures and colonization, while ignoring life-threatening ecological damage. For instance, when I asked Sherene Razack to interview Himani Bannerji for Socialist Studies (the interview unfortunately suffered from poor recording and may be irretrievable), she had to brave the criticisms of anti-racist colleagues who saw this as a betrayal - so many historical materialists and socialists have energetically argued against anti-racist scholarship as a form of false consciousness. This is a problem; and it is a problem for historical materialists and socialists who must prove we are not complicit in racism and other injustices, as we too often are by commission, by omission and through failure to challenge routine, institutionalized forms of racism and other oppressions in our own scholarship and activism. Here, it is impossible to enumerate all the ways that historical materialists and socialists have collaborated. Instead, I offer three ideal-typical (and partially overlapping) arguments that will be familiar to many, emphasizing how they manifest in academia. But they take not dissimilar forms in the world of activism, with sometimes horrendous consequences.

\section{The Lavender Herring Menace}

From her standpoint within the "mainstream", meaning the white middle class women's movement in the late 1960s and early 1970s in the United States, Betty Friedan (see, for instance, Stein 2012, chapter three) urged feminists not to be distracted by demands made by lesbian women. She called these concerns "lavender herrings" and even referred to the "lavender menace" - lesbians as a threat to feminism. This dismissal of lesbian women was a serious problem for the women's movement, answered in the immediate aftermath of Friedan's remarks, in part, by lesbian feminists who with cynical humour formed "The Lavender Menace" movement. Yet variants on the "Lavender herring" argument are familiar and often advanced by historical materialists and socialists: sexuality is irrelevant because it does not matter to fundamental transformations beyond capitalism; race inequality is a distraction from the real 
problem which is class exploitation; gender inequality is a bourgeois concern insofar as it seeks equality for women within existing capitalist structures; the ecological movement is about parks for the urban wealthy and hence a minority, capitalist concern....and so on. In all cases, the aim is to justify a return to "class-only" paradigms and struggles that set aside these other unjust inequalities. This claim is made explicitly, on the grounds that these anti-oppressive concerns are at best irrelevant to, and at worst, a distraction from the main theoretical and ultimately revolutionary task of describing and overthrowing a world capitalist political economy rooted fundamentally in class exploitation.

\section{Saving "Rosa"}

Another, related argument is rooted in efforts to rescue canonical historical materialists theorists and socialists from contamination by feminist theories and other concerns, like ecological struggles, because these are less prestigious concerns. Thus, in October 2013, I attended a conference in Paris, France on "Rosa Luxemberg's Concepts of Democracy and Revolution" sponsored by the International Rosa Luxemburg Society. Reflecting the general tenor of the debates, a contributor argued that one aim of the assembled Luxembourg scholars was to reclaim Luxemburg for political economy. This was necessary against those who sought to identify her with feminism and "birds and flowers", this last after her not infrequent naturalist musings in her abundant personal correspondence, much of it with other socialist women. ${ }^{8}$ Another presenter remarked with some satisfaction that Luxemburg did not identify as a feminist. One the few women presenting at the conference, Sandra Rein, quickly rebutted this last remark. She observed that in addition to specifically addressing the role of women in socialism on various occasions, Luxemburg even wrote to Clara Zetkin: "I'm a feminist now, too". ${ }^{9}$

Of course, those who seek to strip any residue of feminism from Luxemburg while sidelining her attentiveness to nature, see this as an act of rescue. If Luxemburg and her legacy are to be taken seriously then she needs to be identified with the "hard" masculine edge of political economy rather than the apparently separate, secondary and "soft" questions of feminism and any sentimental attachment she might have professed with respect to the natural world. It is a kindness to Luxemburg to avoid presenting her as someone concerned with women's rights and who might be seen as mawkishly interested in birds and flowers. ${ }^{10}$ In such

\footnotetext{
8 Typically, Luxemburg was referred to as "Rosa" although it is difficult to imagine similar discussions about "Karl" and "Fred".

${ }^{9}$ In a November 24, 1918 letter to Clara Zetkin, Luxemburg states plainly: "Now about the agitation on women's issues! Its importance and urgency is clear to us exactly as it is to you" (Adler, Hudis and Laschitza 2011, p.481). Even if she is here emphasizing her support because it was not obvious to Clara Zetkin, the words themselves are explicit enough. Further on, she writes about efforts to produce a regular women's supplement, stating that "a woman's paper must be produced by us here in Berlin....And it is such an urgent matter! Every day lost is a sin" (p.481).

${ }^{10}$ Rationality is here implicitly divorced from caring and feeling, as if emotion distorts rather than informs reason. In the concluding section "Ways forward" I briefly contrast such epistemological claims with Black feminist
} 
ways, incontrovertibly central figures like Luxemburg are re-imagined in "class-only" terms in a revisionist accounting of the historical materialist and socialist canons (see Abigail Bakan (2012) for more on these strategies specifically around socialist-feminisms). In a university and broader social environment in which historical materialism is marginalized, maintaining scholarly respectability by aligning with dominant academic traditions may seem especially urgent.

\section{On the Importance of Being Earnest}

A third, related argument is the importance of being earnest in historical materialist scholarship, both with respect to the topics covered and the authors cited. In mainstream sociology, which is my discipline, one instructive way of discovering whose contributions - and what topics - matter is to look at the syllabi of scholarly authorities. A chair of sociology and "distinguished professor" at a major research university in Canada is not an historical materialist nor socialist. However, he is a specialist on social inequality. His graduate course syllabus on Social Stratification features eighty authors, of which exactly sixteen (20\%) are women. All but one appear to be white women; the men are similarly overwhelmingly white. Sexuality, disability and Indigenous inequalities are entirely absent from the syllabus as explicit concerns. Indeed, even for his session on gender inequality, which includes exactly four articles, all published in the two major American sociological journals, six of the ten listed authors are white men. This professor is objectively engaging with the scholars who count, according to rigorous peer review and objective criteria like journal ranking and citations. Accordingly, he leaves aside those women and racialized men who publish in lesser, "specialized" gender and race inequality journals. He similarly neglects scholars who work on objectively marginalized topics like sexuality, disability and Indigenous inequalities. This is a gauge of the seriousness of his scholarship and the class he teaches. Indeed, it is not improbable to imagine that the professor became officially "distinguished" partly for his sustained engagement with central sociological concerns and relative neglect of objectively-less central questions of inequality. Are historical materialists and socialists much different? Another prominent historical materialist academic, in his syllabus on "Introduction to Political Sociology", mentions thirty authors by name. These range from Marx and Engels to Lenin and Gramsci to Miliband and Poulantzas. Only five (20\%) of those cited are women: Luxemburg, Arendt, Joan Scott, Catherine MacKinnon and Theda Skocpol. All appear to be white, both men and women theorists. Like the distinguished professor of social inequality mentioned above, such politics do not seem to consider sexuality, disability or Indigenous movement as explicit concerns.

I do not think that the search of bibliographies among books and articles by many prominent historical materialist and socialist scholars is likely to be much different. Indeed, the first page of the bibliography of Marxism and Social Movements (Barker 2013), lists twenty-three authors, all men and most apparently white men. The first page of the bibliography of GA Cohen's Rescuing Justice and Equality (20009), lists twenty-two authors of which five (23\%) are

epistemologies (Collins 2009, pp. 269-290) that challenge such assumptions. 
women, all but a few apparently white. Nor is this very different from the kinds of discussions that dominate historical materialist and socialist conferences, at least in my two decades of experience. Consider, for instance, the editorial board of the journal Historical Materialism, which lists twenty editorial board members, of which three (15\%) are women, all apparently white (Historical Materialism 2014). Take the Critical Studies of Global Capitalism network, many of whose members are at least sympathetic to historical materialism and socialism. Their June 28-29, 2013 conference advertised six keynote speakers, including exactly one woman and one male non-white contributor. The Rosa Luxemburg conference held in Paris, France in 2013 that I mentioned earlier had twenty-six speakers, six (23\%) of them women and also including just two non-white presenters. In short, being a serious historical materialist scholar means citing central authors who are mostly white men occupied with concerns of supposedly universal interest, compared to the specialized concerns of feminists, anti-racist, Indigenous and disability scholars. Alternatively, it can be argued that only or overwhelmingly citing white men is no impediment to being considered a serious scholar. At least in this small survey, this seems as true for historical materialists as it is for mainstream theorists.

These are familiar arguments and institutional processes. As Dorothy Smith (1999) describes with respect to feminist sociology, both men and women scholars who seek to be taken seriously cannot afford to engage with so-called "women's issues" (pp.29-44). These are seen as soft, lacking rigor, secondary - hence the need to "save Rosa" from contamination by feminism. One consequence is that historical materialists and socialists who would like to position themselves within the mainstream of an already-marginalized Marxist tradition cannot "afford" to write about disability, Indigenous issues, women, sexuality and more, because they risk placing themselves further on the devalued margins of academia. This is why theorists who are unafraid to tackle the arcana of transformations within the world of finance capital, for instance, argue that it is impossible to consider gender, race, etc. because these subjects are "too complex". They would be embarrassed not to have a minimal grasp of transformations in global finance under capitalism; but they feel no such embarrassment about not having a minimal familiarity with recent developments within feminist, anti-racist, queer, Indigenous and other theories (Smith 1999, pp.39). In such ways do historical materialists and socialists collaborate with institutional practices that separate out and devalue anti-oppression theories as concerned with "soft" and "secondary" issues. The difference with mainstream theory is that historical materialists do this on the grounds of re-centering class analysis, itself devalued within mainstream scholarship.

Yet historical materialist traditions ought to be more sensitive and reflexive about the ways such ordinary, institutionalized practices reproduce the concerns of the powerful as central while marginalizing those of the dominated. As Marx (1845) observed, the ideas of an age are those of the ruling class. Hence, it should not be surprising that white men's concerns dominate within the academy as many white men dominate positions of power in society at large, including in the capitalist class. This is not to argue, absurdly, that white working men are more 
powerful than women billionaires like Lilliane Bettencourt, heir to the L'Oréal fortune, including in the academy. But it does mean recognizing that there is no ground zero of innocence, as Razack and her colleague (Fellow and Razack 1997) might put it. Justifiable claims to being exploited within unequal class relations do not mean absolution from examining inequalities and oppressions, like gender and race, that both combine with and cut across class injustices and which is the case must be empirically established in specific instances. However, since "class only" historical materialists deny the importance of gender, race and other forms of oppression within capitalism as these arise and transform, they consequently fail to see their own routine implication in such forms of oppression, including in their own scholarly work. The most grotesque and horrifying translation of such "intellectual" attitudes into socialist practices, in recent months, was the British Socialist Workers Party's 2013 decision to circumvent "bourgeois" justice by "hearing" charges of rape internally; moreover, so doing with a panel comprised of the male comrades of the accused who allegedly sought to resolve the case by asking questions about the woman's drinking habits (Malik and Cohen 2013). Such developments are an outcome of male-dominated historical materialism and socialist practices that collude with the mainstream to deny the persistent, if changing realities of gender inequalities within world capitalism, including sexual violence against women.

In short, what needs to be acknowledged is the simple empirical fact that, taken together, the working and dominated classes today are in the majority racialized, feminized, queer, disabled and so on. Of course, this is not meant to suggest that such realities exist for the working and dominated classes for all time and in all places in identical ways. For example, it is only recently that very diverse human physical and mental attributes, from blindness to deafness to cerebral palsy to autistism have been grouped together under the category of "disability. Moreover, many reject this label and instead prefer to describe themselves as having non-normative bodies and minds, including for conditions like "cerebral palsy" and "autism" that have only come into being, as such, in recent decades (see, for instance, Overboe 1999). But if disability and even specific medical conditions are historically contingent as specific conditions, historical materialists must still account for the ways that non-normative bodies and minds are disabled within capitalist social relations that seek to do more, faster, and with less expense (Oliver and Barnes 2012, for a recent socialist account). For instance, capitalist profit-seeking in the workplace typically means fewer necessary accommodations for non-standard bodies and minds, even at the cost of lost labour power. This is an important part of the ecological niche for disabling social relations, but does not explain all of the stigma and material inequalities around non-normative minds and bodies; such explanations require other kinds of investigations. Moreover, disability plays out in specific ways that cross-cut with other unjust inequalities. A Black man who is suffering a seizure, whether he is working class or professional, may be read as dangerous - or at a minimum, as a drug addict or drunk, in contemporary North America (Erevelles 2011, p.4); a white bourgeois woman experiencing the same medical event may be read as being "in distress", inspiring compassion and help rather 
than fear. My point here is that the working class is disabled, gendered, racialized and so on, in ways that may well be historically contingent and changing; indeed, even being 'disabled' as a kind of person may be a relatively recent phenomena. But in any concrete empirical instance, class is never a "pure" phenomena outside of these other inequalities, however historically permanent or temporary those prove to be within contemporary world capitalism.

This means that inequalities rooted in race, gender, sexuality, disability and the ongoing colonization of Indigenous peoples - or indeed, whatever unjust social inequalities arise in the future within capitalism- must be part of historical materialist analysis. Fighting such inequalities must be an integral part of everyday socialist practices. Otherwise, the majority of the working class and their concerns are functionally and often literally excluded from socialist practices. When they participate, this majority is at risk of experiencing the same kinds of oppression, including the risks of sexual violence, racist slurs and so on, as well as more insidious, institutionalized discrimination, that are integral to many working class lives within any particular moment of contemporary capitalism. In terms of scholarship, bringing working class voices into the university will necessarily mean more diverse bibliographies, more diverse editorial boards and more diverse speakers than is currently the case in too much historical materialist and socialist scholarship. This diversity may be about 'identity', if identities are understood as historically contingent and social, but this means that questions of diversity and identity are always about power: power that is classed, racialized, masculine and so on. Of course, such efforts are linked to vital struggles to maintain universities as accessible for undergraduates, against rising tuition and trends towards privatization; they are part of broader struggles against unjust class inequalities. But this cannot only be about bringing in a white, male working class. Instead, it is about fighting for all of the working and dominated classes, including women, racialized minorities, the disabled and so on - as well as supporting decolonization struggles and resurgence by Indigenous peoples. Such diversity is about fairly representing the actual diversity within the working and dominated classes, which is important for it's own sake and for making socialism a credible project for liberation for each and all. In addition, bringing in such scholars and distinctive anti-oppressive theories will change historical materialist theories analyses of capitalism and shed new light on what just, socialist societies might look like.

\section{Actually Existing World Capitalism}

Of course, much of this work has already been done, although this is often if not always overlooked within historical materialist scholarship. To cite, inadequately, just a few authors or anthologies in each field from the last decades, there are Black Marxisms and Black Feminist Marxisms (eg., Cedric Robinson 1983, Davies 2007, McDuffie 2011), socialist feminisms and socialist anti-racist feminisms (eg., Ehrenreich 1976, Ingraham and Hennessy 1997, Holmstrom 2002, Bannerji 2005), historical materialist accounts of disability (eg., Nirmala Erevelles 2011; Oliver and Barnes 2012) and works that grapple with the intersection of socialism and sexuality 
(eg., Kinsman 1987, Kinsman undated, Wolff 2009). There are historical materialist concerns with ecology (Foster 2000). In addition, there are those who, like Dorothy Smith (1999), write explicitly "from Marx" and "for people" - in Smith's case with a particular emphasis on unmasking the everyday routine reproduction of gender inequalities within contemporary capitalism. Others are not situated within historical materialist and socialist scholarship, but are in conversation with it. For instance, there are ferocious anti-capitalist critiques from among Indigenous scholars and activists, even if this anti-capitalism is far from exhausting their contribution (eg., see Alfred 2005; Simpson interviewed by Klein 2013). All of these approaches explicitly recognize the importance of grappling with the unjust inequalities of the world capitalist system; none of these approaches think that the only unjust inequality within capitalism- or at least the only one worth analysing, describing and struggling against - is a rareified "class-only" relation of exploitation.

For the purposes of illustration but more importantly, because they highlight critical contributions to our understanding of world capitalism, I examine three aspects of capitalism occulted in too much if not all historical materialist scholarship. Underlying these analyses and descriptions is the argument that historical materialist scholars ought to be embarrassed if they don't have a minimal familiarity with these theories, histories and struggles - and they ought to feel that being competent as historical materialist scholars and activists means demonstrating that familiarity through their scholarly production, teaching and activism. The aim here is not a form of scholarly imperialism that claims all slave revolts, anti-racist struggles, feminist and Indigenous movements, etc. as historical materialism and socialism's own. Rather, the objectiveness is openness towards theories that take such struggles seriously as part of an explicit recognition of the ways that such struggles have shaped everyday life under capitalism. This is necessary if socialists are to avoid reproducing unjust inequalities in their own struggles; and critical if socialists seek to embody, in their own practices, the more just world they seek to bring about.

\section{Indigenous Struggles}

The capitalist system arguably began as world system over five hundred years ago, with the invasion of what to "old Europe" was the "new world" of North and South America but also New Zealand and Australia etc. With the arrival of colonizers, diverse original peoples became colonized, misnamed and denigrated as "Indians" "savages" and in gendered language "squaws" (see LaRocque 2010 for a devastating critique of colonial literary imaginaries perpetuating such concepts). As a consequence of struggles, they later became, in their own (contested) pan-Indigenous lexicon, "Native peoples" "First peoples" "original peoples" and more recently "Indigenous" peoples in relation to settlers; while, of course, never ceasing to be Dene, Métis, and so on. Thus began centuries-long processes of what Marx called "primitive accumulation", the violent dispossession of Indigenous lands, water and skies. Today, such dispossession continues with multinational resource extraction corporations claiming Indigenous lands, 
facilitated by colonial state legislation that asserts private property rights over Indigenous territories. This colonial-capitalist dynamic is rooted in ontologies that assume that the natural world is nothing more than a resource that may be privately owned and that is only of value when profit-making, even at the cost of the destruction of specifically Indigenous ways of living and knowing, critical health problems for local Indigenous peoples and irreversible ecological damage. As Cayuga film-maker Gary Farmer (quoted in Berry 2013) wryly puts it, Indigenous peoples have been on the "cutting edge" of the current economic crisis - and arguably of world colonial capitalism, literally for centuries. In what is called Canada, the mass incarceration of Indigenous men and women, the endemic violence against and murder of Indigenous women and the placement of Indigenous children in "care" in non-Indigenous homes on a scale surpassing the residential school system are just some of the examples of the consequences of ongoing colonialism and capitalist dispossession.

Given centuries of genocide that sought specifically to exterminate Indigenous peoples and contemporary assimilationist policies that seek to strip Indigenous peoples of Indigenous ways of being, knowing and doing, "identity" does matter to Indigenous peoples (eg., Anderson 2000, pp.15-16). However, identity matters not as an abstract or personal possession. Rather, in some Indigenous views, identity is an ontological expression of rootedness in particular spaces and human and non-human relations (Moreton-Robinson 2003), while other Indigenous scholars and actors emphasize the contingent, changing nature of identity for Indigenous persons who, like all human beings, are always in the process of becoming (Hokowhitu 2009). At the same time, identity matters because it is about situatedness in unequal social relations of power; Indigenous-ness means relative lack of power (but not powerlessness) within a still-colonial situations. In other words, 'identity' is about unequal racialized relationships in which 'whiteness' is socially nonracialized against the racialized Indigenous Other. In this context, even if many Indigenous individuals are "technically" working class or members of the army of the unemployed, from historical materialist perspectives, such designations are - at best - unhelpful. They abstract from the specificities of being colonized peoples and they fail utterly to capture the rich lifeworlds of resistance that have been critical to Indigenous survival and resurgence as Indigenous peoples over the last centuries. Being Dene, Haudenosaunee, Nuu-chah-Nulth, and so on is a relationship defined with respect to ancestors, to the natural world, to others in the community and with respect to other Indigenous peoples, as well as relating to shared, but also distinct experiences of colonialism. Even those Indigenous persons who sell their labour power to make a living cannot be reduced to being merely "working class", as if this were the sum of their experiences and histories. Indeed, to insist on this is to objectively collaborate with colonial erasures of Indigenous being and to deny the ongoing realities of racialized colonial power. This does not mean, however, that collaboration is impossible. On the contrary, there are objective reasons for anti-capitalist alliances between many Indigenous peoples and socialists, even if Indigenous communities are complex, contradictory and not without enthusiasts for what Cliff Atleo Jr. (2009) calls Aboriginal neoliberalisms. 
Suggestive of potential alliances, for instance, political theorist Glen Coulthard calls himself a "Dene Communist". In November 2013, he wrote an article outlining his perspectives in a contribution entitled, "For Our Nations to Live, Capitalism Must Die" (2013). Clearly, there are grounds for common cause with socialists here; Coulthard speaks out forcefully for a "massive transformation of the political economy of settler-colonialism" arguing that without it, "our nations will remain parasitic on capitalism and thus on our perpetual exploitation of our lands and labour". But such alliances must accept Indigenous anti-capitalist struggles on their own terms, many of which are rooted in ontologies, epistemologies and axiologies that challenge rationalist, Western historical-materialist premises. Put another way, given the unequal colonial-Indigenous context, the bases of such coalitions must be determined by Indigenous peoples themselves. This is a good in itself, insofar as it reinforces Indigenous autonomy against colonialism. It is a pragmatic precondition for any such alliance, in any case. Moreover, acceptance of such plurality in the anti-capitalist struggle is not antithetical to the idea of a universal struggle against capitalism so long predicted - hoped for - by Marx. Rather, such plurality of purpose, identity or "consciousness" is necessary for a truly universal struggle of each and all against a world capitalist system that is founded upon genocidal horrors and integrally bound up with ongoing colonialism, as well as class exploitation.

\section{Black Power}

The single most well-known Black feminist is arguably Sojourner Truth (1851), a former slave and abolitionist. Her 1851 “Ain't I a Woman!" extemporaneous speech at the Ohio Women's Rights Convention still rings down more than a century later; in it, she affirms her experiences as a former slave who engages in hard physical labour and demands recognition of that reality before the assembled white women whose grievances included being treated as physically fragile and incapable. In other words, Sojourner Truth spoke from her own lived experiences against white women's falsely universalizing description of their oppression within patriarchal capitalism. Despite her heroic efforts and those of many other Black men and women, however, many historical materialists still deny the importance of gender and race to actually-existing capitalism. Empirically, this is impossible to justify. Thus, officially sanctioned slavery existed for four hundred of capitalism's five hundred year old existence. In this system, ten to twelve million individuals were treated as mere commodities, to be bought, sold and subject to extreme violence at the whim of their "owners", on the basis of race. The labour they carried out and the kinds of violence, including sexual violence, that they were subject to was often sharply divided by gender. Official slavery on such a scale is hardly a detail of world capitalist history. Nor are the ongoing wounds of racism, as is clear given the mass incarceration of Black men and women, particularly in the United States, but also Canada, massive economic inequalities linked to race and the enduring reality that many Blacks are still treated, at least in certain "moments" as no more than subhuman "niggers", regardless of class (on this last in particular see Anderson 2011, pp.249-273). 
Achille Mbembe's brilliant Critique de la raison nègre (2013), is a recent example of the kind of contribution that historical materialists and socialists too often -wrongly - ignore, precisely because it centres race as the principle from which to illuminate a universal history of the last centuries, the present, and even into the future. This complex, nuanced if imperfect book examines the multiple and changing significations of what it means to be "nègre", both from the point of view of white slave owners and colonizers and from those reduced to sub-human status under this ideology. Mbembe likewise looks at the material relations, including those of extreme violence (pp.153-189), between whites and "nègres". Throughout, he insists on the 'nègre' as the epitome of the world capitalist system, as well as the product of tendencies to classify humans only to devalue some humans so classified based on race (eg., p.257). Thus, he argues - in unfortunately masculinist language - that the 'nègre', as the man-object (sic), man-currency (sic) is the future within capitalism, as neoliberalism generalizes the human being as a mere instrument for exploitation (including self-exploitation) for future profits (2013, p.14, p.258). But the 'nègre' also offers possibilities for emancipation, historical possibilities that are pregnant in prior victories over slavery, colonization and most recently formal apartheid in South Africa.

Materialists might quarrel with some idealistic tendencies within Mbembe (2013), not least his argument that transcending the idea of race is the central pathway towards freedom from the instrumentalization and objectification of human beings (p.258). But the common ground is more important than any divergences, as he offers a history of the world from the point of view of the changing and complex significations and realities of the 'nègre'. These are vital insights for historical materialists seeking to think about the changing nature of world capitalism over centuries, including the ways that material relations of racial inequality emblematically in the slave trade - are reflected in, and legitimated by complex racist ideologies in popular and elite cultures. Moreover, Mbembe's history ought to be critical to informing socialist practices, as he insists on the importance of appreciating the unique and universal humanity of each and all against racial inequalities that deny this to human beings transformed into nothing more than 'nègres'. Socialists argue that the liberation of the working class will require the overthrow of class inequalities; but equally, with Mbembe as with prior scholars and activists, it is clear that such liberation cannot come about as long as masses are effectively relegated to sub-human status through racisms. Such racisms are shape-shifting but constant features of a world capitalism that tends to reduce human beings to nothing more than commodities: besides the enormous human importance of this reality, this is why the 'nègre' as a slave-commodity is so critical analytically, illuminating this central feature of capitalist dynamics.

\section{Gay and Lesbian Liberation}

Ian Hacking (2002) quotes Arnold Davidson as saying that the "pervert" was only invented in the 19th century (p.99, in a chapter with the wonderful title "Making Up People"). It is only relatively recently within Western capitalist societies that it has become possible to 
classify human beings as specific "kinds" of people - heterosexual, gay, lesbian, bisexual - based on the gender of those involved in sexual relationships. This is not to say that persecution of those engaged in same-gender relations only arose with the social emergence (to avoid the metaphor of "social invention" that implies conscious planning) of gay and lesbian kinds of people in the 19th century. Rather, it is only to observe that this is a historically-contingent and relatively recent development within world capitalism to envisage people as 'kinds' in this way. Of course, in contrast to gay and lesbian liberation, queer emancipation is grounded in the idea of transcending essentialist gender and sexual binaries. My own feeling is that gay and lesbian liberation are necessary reforms within today's capitalism; with queer revolution perhaps the ultimate goal. In contrast, with Friedan, too many historical materialists and socialists have treated sexuality as a "lavender herring", at best irrelevant too socialist struggles and at worse a distraction from the main issue of class. Such a stance requires serious distortions of working class struggles, as well as the pragmatics of working class life as a gay and lesbian person.

Indeed, in the contemporary moment of capitalism; gay and lesbian rights are obviously working class rights. Hence, for instance, gay and lesbian workers must choose where they live and where they work based in large part upon which state jurisdictions recognize their relationships with one another and with their children, biological or not. Moreover, while marriage and the nuclear family may be bourgeois institutions, currently many state and many corporate benefits for working class families depend upon the formal, legal recognition of participation in such institutions. In many places in North America and Europe, for instance, gay and lesbian parents of non-biological children are not recognized as parents; in the event of separation or death from the biological parent, or in the absence of a biological link, these children are at risk of being removed from one or more of their parents, who in legal terms are nothing more than strangers. This is an intolerable state of affairs. On the principle of "An injury to one is an injury to all!", working class and socialist movements must struggle for gay and lesbian rights to choose marriage and to choose legally-recognized family relationships, for those who wish it. This is often a pragmatic necessary to give workers the freedom to move across jurisdictions and workplaces, a mobility vital to worker's immediate relative power vis-a-vis the employer. But such rights likewise strongly challenge stigmatization of same-gender relationships as unnatural. Indeed, it should go without saying - but too often doesn't - that unthinking heteronormative language must be resisted by socialists, so that lesbian and gay working class people feel that they may fully participate in socialist movements and in broader society and politics. In other parts of the world, where same-gender relations are punishable by death, efforts to abolish the death penalty must likewise be pursued alongside international support for same-gender relationships and families. The point is that working class concerns today inevitably include specific exclusions and injustices experienced by gay and lesbian relationships and families. When historical materialist analyses and socialist struggles ignore this, they abandon these gay and lesbian members of the working class in their everyday struggles - even if these are only narrowed defined as being about access to social welfare 
protections for themselves, partners and their families.

Ultimately, having these histories written and struggles undertaken is related to a politics of respect and of representation. But here, respect is related to claims about the ontologically fully human character of those who have been dismissed as less-than-human, as 'nègres' 'savages' and so on. Representation is about the realities that there are political inequalities attached to who you are socially eg., as with racialized women having less authority, in many mainstream settings, than non-racialized men and so on. But you can justify similar politics on the narrow historical materialist grounds that consciousness emerges from experiences of struggle and that therefore those who best know these struggles are those who live them. That is, generally speaking, it has been women who (rightly) have been at the forefront of socialist feminisms. It is gay and lesbian socialists who have written about and engaged in gay and lesbian socialist struggles. It is Black socialists who have elaborated Black historical materialisms. Put another way, if we take all of the working class to be ontologically fully human, than we need to ensure that the diversity of working class and subaltern class experiences, the analyses arising from these and actions that these imply, are part of our debates and practices. We cannot know these in advance; what social differences become the bases for unjust social inequalities within capitalism will change over time, taking shape-shifting forms. Right now, it is certainly legitimate to argue that race, gender and sexuality, among other unequal relations, are relevant concerns to struggles among the working and dominated classes. In the future, there may be issues that we cannot even conceive of now that will become relevant to historical materialist and socialist theories: for instance, there is the recent emergence in Western polities of specific rights around intersex individuals. Moreover, this argument rests on the conviction that who speaks matters, not only on the epistemological grounds of gaining multiple perspectives, perspectives that are rooted in where actors are situated within unequal social relations, but on the moral grounds of respect for each and all. This may be especially obvious with respect to Indigenous peoples, who have so often been catalogued, inspected, measures, dissected, including in human "zoos", in processes of research that are extensions of colonial power (Smith 1999). But it holds true more generally: in the slogan the disability movement has made it's own but that serves as a useful guide for socialists, too, "Nothing about us, without us!"

What I have sketched here holds, too, with respect to other vital concerns. That is, historical materialism and socialism must be informed by the everyday struggles and injustices faced by all of the working and dominated classes. For instance, insofar as the working and dominated classes include persons who are disabled by social relations and institutions made exclusively for 'standard' minds and bodies, disability must be taken into account into historical materialist theory. I have already raised some of these dynamics above. But, for instance, Deaf movements maintain that Deafness is a not an impairment to be cured but a cultural difference that is stigmatized. Deafness becomes disabling in a predominantly hearing world that fails to encourage bilingualism with Deaf sign language (see Ladd 2003 for an overview). This is a fair critique of many socialist movements, which take for granted non-Deafness, as well as the mainstream. So the question becomes how to make socialist movements enabling, not disabling, 
in everyday practices, while striving to create social relations that do not disable those in the working and dominated classes with non-standard bodies and minds, including those who identify as Deaf.

At the same time - and I have explored this less in the instances above -- historical materialist theory does pose questions for anti-oppressive theories, including disability movements. For instance, among other questions, 'crip' theory asks, to paraphrase: what would it mean to desire the disabled body? (McCruer 2011). This question helpfully challenges the stigmatization and desexualization of many disabled persons. But such a question evades the issues that arise, for instance, around criminally negligent factory owners or even from ordinary strain that creates disabilities through repetitive working class labour. Put explicitly with respect to a single, notorious case: Did Union Carbide "gift" the workers who survived Bhopal with serious injuries, with new, different but desirable bodies? (see Davidson 2008, pp.168-196). Or did Union Carbide create preventable impairments for which they must be held accountable? These are conversations that must be held, not only in the specialized academic disciplines of disability studies but in historical materialist analysis. Likewise, if socialist practices are to address such issues in meaningful ways, the full participation of disabled persons and those with non-normative minds and bodies has to be taken seriously in socialist struggles. Disability may be an historically contingent as an idea, but disabling social relations are a fact for many working class and dominated people; therefore disability movements must be part of the conversation within socialist struggles.

Not every historical materialist and not every socialist can be an expert in all aspects of every working class experience - the experiences of women, minoritized others, the disabled and so on. But every historical materialist and socialist should be at least minimally competent and alert to emergent claims around unjust inequalities. Moreover, if the whole range of working class experience was a more regular feature of historical materialist conferences, scholarship, and bibliographies, many of these experiences would be less 'exotic' to and less difficult to grasp within socialist thinking. This means that we need to actively reach out and find out what is necessary for our conversations and struggles to become relevant and accessible to the whole working class. Again, the aim is not to dissolve already-existing and necessary separate spaces, for instance, where Black socialist feminists can, will and should discuss and exchange amongst themselves as relatively "safe" shared spaces where, temporarily, gendered and racialized inequalities may be bracketed. But there needs to be many spaces and places where such insights contribute, in ordinary, ongoing ways, to the development of historical materialist analyses and socialist struggles. This happens too infrequently. And yes, historical materialist scholars who do so engage will lose prestige by association with concerns "objectively" devalued as lesser; but it seems to me this is the price to pay for historical materialisms and socialisms that are relevant to all working and dominated classes, in all of their variety and complexity.

\section{Ways Ahead - and the World to Win}


Do I think it will be easy for historical materialists and socialists to embrace questions that too many have so often, and so long, denied? No. There will be challenges.

For scholars and activists, one issue is that narrow "class-only" versions of historical materialism are traditionally rooted in quite different paradigms from other anti-oppressive struggles. For instance, GA Cohen operates from an analytical philosophy framework that is resolutely Habermasian insofar as it emphasizes rational-critical debate among individuals whose personal background is ideally irrelevant to the conversation, which will be judged in strictly objective logical terms (Habermas, Lennox and Lennox 1974). Symptomatically, for instance, GA Cohen was disturbed that his commitment to socialism was rooted in his parents' socialism - he feared this background contaminated his analysis, implying he was attached to socialism on the irrational grounds of intellectual and political inheritance (2001, pp.7-19; Cohen referred to this and related problems as "the paradoxes of conviction"). In contrast, American Black feminist approaches to liberation, which ought to inspire (at least some forms of) historical materialism and socialism, instead emphasize an experiential politics of caring and personal accountability (Collins 2009 pp.269-290). Here, truth is rooted in personal experience and biography, which do not contaminate but vitally inform research. In this approach, too, emotions inform rationality and do not take away from it. For instance, we believe Aretha Franklin's call for R-E-S-P-E-C-T for Black women because of how she sings and because of who she is, not in spite of her powerful emotion and stake in the struggle (Collins 2009, p. 127).

These are serious divergences about what constitutes meaningful argument; they are not complementary approaches. My own feeling is that many historical materialists are not sufficiently reflexive about their own Habermasian assumptions nor sufficiently versed with respect to alternative epistemological paradigms. If they were, it might be easier to recognize the validity of claims made, once it is accepted that the paradigms underlying these claims are different. Does this mean "anything goes"? (Feyerabend 2010, pp.7-12). I suppose my hedged answer, following Feyerabend, is that the future of historical materialism and socialism are epistemologically plural. I don't find this worrying. In the first place, since human beings are social and since ways of knowing are rooted in lived experiences, as historical materialists observe, it is not surprising that human beings develop multiple ways of knowing. This plurality is rooted in the diversity of lived experience which, again, includes but is not reducible to some "pure" class experience. That inevitably suggests epistemological plurality, not sameness. Moreover, such plurality seems to me rich with possibilities and not (only) fraught with problems of incommensurability as some class-only theories emphasize as they seek to encourage a "universal" - by which, too often, they mean homogenous, uniform (white, male)class consciousness. By analogy, it is useful to have a common language, currently English, across many academic settings as it enables the exchange of ideas; but it is critically important that we express ourselves in other languages, too, because these embed different worldviews that enable insights that are less obvious in English. We need to become much more "multilingual" and 
fluent in different paradigms, rooted in the diversity of working class and subaltern experiences.

A second issue for historical materialists and socialists is that the complexity of actually-lived class experience may seem overwhelming. Indeed, here, I have only been able to make gestures towards what a more truly universal historical materialist theory and socialist practice might look like. Even granting this is a desirable course of action, is it mission impossible? My own argument, as outlined above, is not that we all have to be expert in all aspects of actually-lived capitalism. Of course, we will have insights from our own lived experiences into many of these complexities, as women, as minoritized individuals, as persons who are disabled by social relations, institutions and infrastructures built around normative minds and bodies. These can powerfully inform historical materialist research and socialist practice. However, we do need to be at least minimally competent in a wide range of areas, for instance, with respect to colonial-capitalism and Indigenous resistance to this, on the histories of Black socialist-feminist challenges, and concerning working class gay and lesbian and queer struggles - or whatever struggles against unjust inequalities arise since many of them cannot be anticipated theoretically. If we make more efforts to be relevant in these areas, we will at the same time make historical materialist theory and socialist spaces more hospitable to those working on these questions. Such concerns will come to seem less exotic, as noted above, the more they are incorporated into historical materialist canons and normal socialist practices.

Of course, in making such arguments, I make no claim to originality. But the case still has to be put forward and defended, on analytical, empirical, normative and pragmatic grounds. The consequence will be empirically-richer and more accurate histories and analyses of actually-existing centuries-old capitalism. Socialist practices will better fulfill their promise of "being the change we want to see", when they challenge unjust inequalities around race, gender, disability, sexuality and more that currently prevent the full and unalienated expression of too many in the working and other subjugated classes. On pragmatic grounds, it is true that the relative and increasing dominance of capital has marginalized historical materialism and socialism, a decline that maps onto the defeat of much of the formally organized working and dominated classes in the 1970s; although important gains by women's movements, Indigenous movements, anti-racist movements and so on, were victories that even when not socialist ought to be celebrated and seen as instructive for socialists, as they have created, if incrementally and inevitably imperfectly, spaces for non-alienated human expression and so helped shift some power back into the hands of relatively disempowered people. Combatting a powerful capitalist class depends more than ever on mobilizing the whole working class, as well as other subjugated classes and peoples, which requires attentiveness to the complexity of class and subaltern experiences and the claims arising from these. Ultimately, however, I think that the anti-oppressive struggles discussed here are necessary parts of historical materialism and socialism on simple, human grounds. Marx (1865) liked to put it this way, in the phrase he borrowed from the ancient Roman playwright Terence: "Nothing human is alien to me". It's about time that historical materialists and socialists wrote, spoke and acted as if we believed that to be true. 


\section{References}

Adler, Georg, Peter Hudis and Anneliese Laschitza. 2011. The Letters of Rosa Luxemburg. Verso.

Alfred, G. R. 2005. Wasase: Indigenous Pathways of Action and Freedom. University of Toronto Press.

Anderson, Kim. 2000. A Recognition of Being: Reconstructing Native Womanhood. Canadian Scholars' Press.

Atleo Jr., Cliff. 2009. "From Indigenous Nationhood to Aboriginal Neoliberal Economic Development: Charting the Evolution of Indigenous-Settler Relationships in Canada.” Available at:

http://socialeconomyhub.ca/sites/socialeconomyhub.ca/files/CAtleoCSEHubPaperoctobe r09.pdf

Bakan, Abigail. 2012. "Marxism, Feminism and Epistemological Dissonance." Socialist Studies 8 (2):60-84.

Bannerji, Himani. 2005. "Building from Marx: Reflections on Class and Race." Social Justice. 32 (4): 144-160.

Barker, Colin et al, Editors. 2013. Marxism and Social Movements. Blackwell Publishing.

Belkhir, Jean. 1994. “The Failure and Revival of Marxism on Race, Gender \& Class Issues.” Race, Sex \& Class. 2(1) 79-107.

Berry, Carol. 2013. “Gary Farmer, Idle No More, 'Consumerization', Mining Fallout and Indian Humour." Indian Country Today, Media Network. March 18. Accessible at: http://indiancountrytodaymedianetwork.com/2013/03/18/gary-farmer-idle-no-more-con sumerization-mining-fallout-and-indian-humor-148240

Cohen, G.A. 2001. If You're An Egalitarian, How Come You're So Rich? Harvard University Press.

Cohen, G.A.. 2009. Rescuing justice and equality. Harvard University Press. 
Collins, Patricia Hill. 2009. Black Feminist Thought: Knowledge, Consciousness and the Politics of Empowerment. Routledge. Second edition.

Coulthard, Glen. 2013. "For Our Nations to Live, Capitalism Must Die!” Available at: http://nationsrising.org/for-our-nations-to-live-capitalism-must-die/

Davidson, Michael. 2008. Concerto for the Left Hand: Disability and the Defamiliar Body. University of Michigan Press.

Davies, Carole Boyce. 2007. Left of Karl Marx: The Political Life of Black Communist Claudia Jones. Duke University Press.

Ehrenreich, Barbara. 1976. What is Socialist Feminism? Nationwide Women's Program.

Erevelles, Nirmala. 2011. Disabling and Difference in Global Contexts: Enabling a Transformative Body Politic. Palgrave.

Fellows, Mary Louise, and Sherene Razack. 1997. "The Race to Innocence: Confronting Hierarchical Relations among Women.” The Journal of Gender, Race \& Justice. 1: 335.

Foster, John Bellamy. 2000. Marx’s ecology: Materialism and nature. New York University Press.

Gimenez, Martha E.. 2001. Marxism, and Class, Gender, and Race: Rethinking the Trilogy Race, Gender \& Class, 8 (2): 23-33

Feyerabend, Paul. 2010. Against Method. Fourth Edition. New Left Books.

Habermas, Jürgen, Sara Lennox, and Frank Lennox. (1974). "The Public Sphere: An Encyclopedia Article" New German Critique (3): 49-55.

Hacking, Ian. 2002. Historical Ontology. Springer Netherlands.

Hacking, Ian. 1998. Mad travelers: Reflections on the Reality of Transient Mental Illnesses. Harvard University.

Hokowhitu, Brendan. 2009. "Indigenous existentialism and the body." Cultural Studies Review15.2: 101-18.

Holmstrom, Nancy Christina Louise, Editor. 2002. The Socialist Feminist Project: A 
Contemporary Reader in Theory and Politics. Monthly Review Press.

hooks, bell. 2000. Feminist Theory: From Margin to Center. Pluto Press.

Hull, Gloria T., Patricia Bell-Scott, and Barbara Smith, Editors. 1982.. All the Women are White, all the Blacks are Men, But Some of Us are Brave: Black Women's Studies. Feminist Press at CUNY.

Ingraham, Chrys, and Rosemary Hennessy. 1997. Materialist Feminism: A Reader in Class, Difference, and Women's Lives.

Kinsman, Gary. 1987. The Regulation of Desire: Sexuality in Canada. Montreal: Black Rose Books.

Kinsman, Gary. Undated. Workers of the World Caress: An Interview with Gary Kinsman on Gay and Lesbian Organizing in Toronto in the 1970s. Interviewed by Deborah Brock. From: http://www.yorku.ca/lefthist/online/brock kinsman.html

Henderson, Sakej Youngblood. Forthcoming. "The Split Head Resistance: The Contradictions of Using Colonial Law for Aboriginal Justice" in Indigenous Resistance and Resurgence, edited by Elaine Coburn. Fernwood Press.

Holloway, John. 2012. "Variations on Different Themes: A Response." Journal of Classical Sociology12 (2): 332-348.

Klein, Naomi. 2013. "Dancing the World Into Being: A Conversation with Idle No More's Leanne Simpson". Yes Magazine. . From:

http://www.yesmagazine.org/peace-justice/dancing-the-world-into-being-a-conversation -with-idle-no-more-leanne-simpson

Ladd, Paddy. 2003. Understanding Deaf Culture: In Search of Deafhood. Multilingual Matters.

LaRocque, Emma. 2010. When the Other is Me: Native Resistance Discourse 1850-1990. University of Manitoba Press.

Malik, Shiv and Nick Cohen. 2013. "Socialist Workers Party Leadership Under Fire over Rape Kangaroo Court”. The Guardian. March 9. Accessible at:

http://www.theguardian.com/society/2013/mar/09/socialist-workers-party-rape-kangaro o-court 
Marx, Karl. 1888. “Theses on Fuerbach”. From:

http://www.marxists.org/archive/marx/works/1845/theses/theses.htm

Marx, Karl. 1865. “Confession”. From: http://www.marxists.org/archive/marx/works/1865/04/01.htm. Last accessed April 2014.

Marx, Karl. 1845. “Ruling Class and Ruling Ideas”. From: http://www.marxists.org/archive/marx/works/1845/german-ideology/ch01b.htm

Mbembe, Achille. 2013. Critique de la Raison Nègre. La Découverte.

McCoird, Catherine Hodge. 2008. "Eleanor Burke Leacock and Intersectionality: Materialism, Dialectics, and Transformation.” Race, Gender \& Class, 15 (1-2):24-41

McDuffie, Erik S. 2011. Sojourning for Freedom: Black Women, American Communism, and the Making of Black Left Feminism. Duke University Press.

McRuer, Robert.2011. "Disabling Sex: Notes for a Crip Theory of Sexuality." GLQ: A Journal of Lesbian and Gay Studies (17)1: 107-117.

Moreton-Robinson, Aileen. 2003. "I Still Call Australia Home: Indigenous Belongings and Place in a White Postcolonising Society". Uprootings/Regroundings:Questions of Home and Migration. 23-40.

Oliver, Michael and Colin Barnes. 2012. The New Politics of Disablement. Palgrave MacMillan.

Overboe, James. 1999. "Difference in Itself: Validating Disabled People's Lived Experience." Body \& Society, 5(4), 17-29.

Piketty, Thomas. 2013. Le Capital au XXIe siècle. Seuil.

Robinson,Cedric J. 1983. Black Marxism: The Making of the Black Radical Tradition. University of North Carolina Press.

Scheper-Hughes, Nancy. 2001. "Commodity fetishism in organs trafficking." Body and Society 7 (2-3): 31-62.

Smith, Dorothy E. 1999. Writing the Social: Critique, Theory, and Investigations. University of 


\section{Toronto Press.}

Smith, Linda Tuhiwai. 1999. Decolonizing Methodologies: Research and Indigenous peoples. Zed books.

Stein, Marc. 2012. Rethinking the Gay and Lesbian Movement. Routledge.

Truth, Sojourner. 1851. “Ain't I a Woman!”

Accessible at: http://www.emersonkent.com/speeches/ain_t_i_a_woman.htm

Vrousalis, Nicholas. 2012. "Jazz Bands, Camping Trips and Decommodification: GA Cohen on Community." Socialist Studies/Etudes Socialistes 8 (1): 141-163 